\title{
Galapagos' Wildlife Biodiversity Would be Affected by Vancomycin Resistant Enterococci
}

\author{
Racines Medina Diana Carolina* \\ Universidad Central del Ecuador, Ecuador
}

Submission: May 28, 2019; Published: June 13, 2019

*Corresponding author: Diana Carolina, Universidad Central del Ecuador, Jeronimo Leiton y Gilberto Gato Sobral, UIO, EC 170129, Ecuador

\section{Abstract}

Vancomycin is a high priority antibiotic to human health according to World Health Organization, because it is the last option to the treatment in bacterial infections. There are many vancomycin resistant bacteria like enterococci, which is a kind of bacteria that is part of the normal microbiota of mucous surfaces and intestinal tract of domestic animals, wild animals and humans. Enterococci have the presence of different multidrug resistant genes that are essentials to their survival. There are nine different genes of resistance to vancomycin, but the gen Van A and the gen Van B are the most common genes with high prevalence in this kind of bacteria. There are many reports about vancomycin resistance in worldwide bacterial infections in humans and in animals. Also, there are reports about enterococci that were isolated from rectal swabs of finches, marine and terrestrial iguanas from Galapagos' isles, but those hasn't been confirmed if are vancomycin resistant enterococci.

Keywords: Antibiotic resistance; Finches; Galapagos; Vancomycin; Bacterial infections; Bacteria; Plasmids; Enterococci; Vancomycin resistance; Antibiotic; Glico peptides; Polymerase chain Reaction; Lactobacillus's; Avoparcina; Sentinel birds; Galapagos; Enterococcus Faecium

Abbreviations: VRE: Vancomycin Resistant Enterococci; WHO: World Health Organization; PCR: Polymerase Chain Reaction

\section{Introduction}

Enterococcus spp. is a gender of gram-positive bacteria [1]. They are on mucous surfaces and are part of the normal intestinal microbiota of all the animals including human [1-3], Galapagos' finches [4,5] and also marine and terrestrial iguanas from Galapagos [6]. Enterococci also has been isolated from water, oil, food products, diary food, plants [1,5] and soil [7]. Enterococcus faecium is a specie of enterococci that may live on objects surfaces many years [8]. This gender of bacteria has very important genetics characteristics to their survival and adaptation in the environmental [9-11] like mutations and genes changings in horizontal way with transposons or plasmids $[2,10,12,13]$. An example of this kind of transference of genes is when they get multidrug resistance genes; a principal characteristic of enterococci; like the vancomycin resistance $[2,10]$.

Vancomycin is a high priority antibiotic in human health to World Health Organization (WHO) with importance in public health $[1,2,14]$ because it applies to the five WHO' criteria, which are:

1. To be the unique antibiotic to bacterial infections,

2. Its use in bacterial infections can cause the probability of to make resistance genes,
3. Be the unique option to treat people with bacterial infections,

4. Its high prevalence of use may make a resistant bacteria and

5. .There are reports about transmission of resistance genes in bacteria [14].

So, vancomycin is used when there is not any other drug to treat bacterial infections, so its resistance is a worldwide problem in human medicine and animal medicine, which may come with alarming consequences like the inexistence of efficient antibiotics against bacterial infections $[11,15]$. Vancomycin resistance is by nine different resistance against Glico peptides that are associated to different genes $[1,16]$ which are: Van A, Van B, Van C, VanC1, VanC2, VanC3, VanC4, Van D, Van E, Van G, Van L, Van M y Van N [1]. The first two are commonly found on enterococci isolated, and the most important in clinic cases [1], [17-19]. The other genes are rarely found [1]. There are many reports about Vancomycin resistance in human and animal health, and in the environmental [12]. In humans, investigators isolated VRE in different scenarios for many years. A Massachusetts' hospital took samples in 2016 and 2017, 83.7\% were Enterococcus faecium resistant to vancomycin [20]. In 30 countries of Europe Union and European 
Economic Area, the resistance to vancomycin up from 10.4\% to $14.9 \%$ since 2010 to 2017, this data was taken by European Antimicrobial Resistance Surveillance Network [12]. In Germany, scientists isolated Enterococcus faecium resistant to vancomycin in 773 patients form a hospital since 2010 to 2016, from where 87.5\% had Van B gene and $21.5 \%$ the Van A gen [8]. Also, isolated VRE in patients hospitalized in King Abdulaziz University Hospital between 2014 and 2015, where identified Van A gen in five of six samples, and Van B gen in one sample by Polymerase Chain Reaction (PCR). VanC1/C2 genes were not detected in any sample [21].

Those cases of VRE are an epidemic disease nowadays in different places around the world [1,9]. There isn't a lot of information of VRE in the environmental and their genes of resistance, but VRE has been isolated in 308 samples of sewage water [16], and from the soil of an isle of Sao Pablo. This samples were analyzed by PCR with some primers to the genes Van A, Van $B$ and Van C, where just identified the presence of Van A and VanC1 [7]. While in animal health, scientists have been investigating more about VRE in production and company animals, and less in wild animals. In Poland in 2018, isolated Enterococcus spp. In 426 mastitis milk samples, where just $0.94 \%$ were VRE [22]. Also, in Czech Republic isolated 121 enterococci resistant to many drugs in 2012, 2013 and 2014 from fecal samples of rooks, sewage water, pheasants, people hospitalized, one dog and chickens of a farm and they found the gene Van A in all of them [18]. But in isolated of VRE from fecal samples of pork farms in Denmark, found the gen Van B and Van G, less the gen Van A, determining the presence of those gens 25 years later of the banned of avoparcin a like growing promotor in 1997 [13,23]. Finches, like mentioned before, have enterococci in their intestinal microbiota [5]. In 2018 investigated on Galapagos' isles including Santa Cruz. In this isle, isolated Lactobacillus's; an order of enterococci; in 21 finches from the gender Geospiza with 92\% of presence from all kind of bacteria in fecal samples, with which they conclude that the kind of alimentation of finches doesn't affect the growing selection of Lactobacillus's, taking into consideration the historic evolution of finches $[4,24]$.

Meanwhile, in 2016 scientists studied the human presence and the biodiversity of bacteria in fecal samples of finches Geospiza in Galapagos. They determined that the human presence affects the diversity of bacteria, where they were found more in small ground finches than medium ground finches [4]. Wild birds are vulnerable to acquire drug's resistance because are sentinel birds; checking them we can value the environmental impact where they live and their facilities to take bacteria from many sources. Other reasons why wild birds take environmental bacteria so easily are because they are bacteria reservoirs with different genes of resistance, and because they can spread those bacteria easily in different places [25]. Finches are wild and endemic Galapagos' birds, and they can spread bacteria with resistant genes in an easily way between many places and for their contact with humans [25]. Also, reports about the presence of enterococci in fecal samples of finches from
Galapagos [4,5] don't discard the possibility of the presence of VRE in these animals.

\section{References}

1. Filippis I, McKee M (2013) "Enterococcus, in Molecular Typing in Bacterial infections. ( $1^{\text {st }}$ edn), Humana Press, New York, USA, pp. 17-26.

2. Quinn P, Markey B, Leonard F, Fit Patrick E, Fanning S, et al. (2011) Antimicrobial Resistance, in Veterinary microbiology and microbial disease. ( $\left.2^{\text {nd }} e d n\right)$, Wiley - Blackwell, Iowa, USA, pp. 495-517.

3. Krista A Dubin, Deepti Mathur, Peter T McKenney, Bradford P Taylor, Eric R Littmann, et al. (2019) Diversification and evolution of vancomycinresistant Enterococcus faecium during intestinal domination. Infect Immun p. 1-25.

4. Michel AJ, Lewis M Ward, Shana K Goffredi, Katherine S Dawson, Daniel T Baldassarre, et al. (2018) The gut of the finch: uniqueness of the gut microbiome of the Galápagos vampire finch. Microbiome 6(167): 1-14.

5. Beukers AG (2017) Comparative genomics of Enterococcus spp. isolated from bovine feces. BMC Microbiol 17(52): 1-18.

6. Hong PY, Mao Y, Ortiz-Kofoed S, Shah R, Cann I, et al. (2014) Metagenomic-Based Study of the Phylogenetic and Functional Gene Diversity in Galápagos Land and Marine Iguanas. Microb Ecol 69(2): 444-456.

7. Vanessa Silva, Fernando Peixoto, Gilberto Igrejas, Carolina Parelho, Patrícia Garcia, et al. (2018) "First Report on vanA-Enterococcus faecalis Recovered from Soils Subjected to Long-Term Livestock Agricultural Practices in Azores Archipelago." Int J Environ Res 12(1): 39-44.

8. Liese J, Schüle L, Oberhettinger P, Tschörner L, Nguyen T, et al. (2019) Expansion of Vancomycin-resistant Enterococcus faecium in an academic tertiary hospital in Southwest Germany: a large-scale whole genome-based outbreak investigation. Antimicrob Agents Chemother 63(5): e01978-019718.

9. Eliandro Reis Tavares, Lucas Fernando da Silva, Alexandre Tadachi Morey, Admilton Gonçalves de Oliveira, Sergio Paulo Dejato da Rocha, et al. (2019) "Draft Genome Sequence of Vancomycin-Resistant Enterococcus faecium UEL170 (Sequence Type 412), Isolated from a Patient with Urinary Tract Infection in a Tertiary Hospital in Southern Brazil. Microbiol Resour Announc 8(7): 1-3.

10. Weaver KE (2019) Enterococcal Genetics. Microbiol Spectr 7(2): 312 331.

11. Laxminarayan $R$ (2014) The coming crisis in antibiotics.

12. ECDC (2018) Surveillance of antimicrobial resistance in Europe.

13. Birkegård AC, Græsbøll K, Clasen J, Halasa T, Toft N, et al. (2019) Continuing occurrence of vancomycin resistance determinants in Danish pig farms 20 years after removing exposure to avoparcin, Vet Microbiol 232: 84-88.

14. OMS (2017) WHO list of Critically Important Antimicrobials for Human Medicine (WHO CIA list).

15. McKenna M (2015) What do we do when antibiotics don't work anymore?

16. Sanderson H, Ortega-Polo R, McDermott K, Zaheer R, Brown RS, et al. (2019) Comparison of biochemical and genotypic speciation methods for vancomycin-resistant enterococci isolated from urban wastewater treatment plants. J Microbiol Methods 161: 102-110.

17. Dokyun Kim, Hyukmin Lee, Eun-Jeong Yoon, Jun Sung Hong, Jong Hee Shin, et al. (2019) Clinical prognoses of patients with a bloodstream infection caused by ampicillin-susceptible but penicillin-resistant Enterococcus faecalis: prospective observational study. Antimicrob Agents Chemother p. 1-20. 
18. Oravcova V, Kolar M, Literak I (2019) Highly variable vancomycinresistant enterococci in the north-eastern part of the Czech Republic. Lett Appl Microbiol.

19. Lam MM, Seemann T, Tobias NJ, Chen H, Haring V, et al. (2013) Comparative analysis of the complete genome of an epidemic hospital sequence type 203 clone of vancomycin-resistant Enterococcus faecium. BMC Genomics 14(1): 595.

20. Ward DV, Hoss AG, Kolde R, van Aggelen HC, Loving J, et al., (2019) Integration of genomic and clinical data augments surveillance of healthcare-acquired infections. Infect. Control Hosp. Epidemiol 1(7): 1-7.

21. Muhammad Farman, Muhammad Yasir, Rashad R Al-Hindi, Suha A Farraj, Asif A Jiman-Fatani, et al., (2019) Genomic analysis of multidrugresistant clinical Enterococcus faecalis isolates for antimicrobial resistance genes and virulence factors from the western region of Saudi Arabia. Antimicrob. Resist. Infect. Control 8(1): 55.

22. Rózańska H, Lewtak-Piłat A, Kubajka M, Weiner M (2019) Occurrence of enterococci in mastitic cow's milk and their antimicrobial resistance. J Vet Res 63(1): 93-97.

23. Brussels (1997) Ban on the antibiotic 'Avoparcin' in animal feed Europe Union, 1997.

24. Knutie SA, Chaves JA, Gotanda KM (2019) Human activity can influence the gut microbiota of Darwin's finches in the Galapagos Islands. Mol Ecol p mec 15088

25. Bonnedahl J, Järhult JD (2014) Antibiotic resistance in wild birds. Ups Med Sci 119(2): 113-116.

\section{Your next submission with Juniper Publishers will reach you the below assets}

- Quality Editorial service

- Swift Peer Review

- Reprints availability

- E-prints Service

- Manuscript Podcast for convenient understanding

- Global attainment for your research

- Manuscript accessibility in different formats

( Pdf, E-pub, Full Text, Audio)

- Unceasing customer service

Track the below URL for one-step submission https://juniperpublishers.com/online-submission.php 